\title{
Performance of Cement for Immobilizing Strontium Waste in Saline Environment
}

\author{
Susetyo Hario Putero*, Widya Rosita
}

Department of Engineering Physics, Universitas Gadjah Mada, Yogyakarta, Indonesia.

Email: "susetyo@ugm.ac.id

Received October $1^{\text {st }}, 2013$; revised November $21^{\text {st }}, 2013$; accepted December $7^{\text {th }}, 2013$

Copyright (C) 2013 Susetyo Hario Putero, Widya Rosita. This is an open access article distributed under the Creative Commons Attribution License, which permits unrestricted use, distribution, and reproduction in any medium, provided the original work is properly cited.

\begin{abstract}
For solving the radioactive waste storage problem, there is an idea to store immobilized waste at deep sea. Solidifier material, such as cement should be resistance to saline environment for deep sea storage. So, this research objective is to study the performance of cementation method in immobilizing strontium waste in saline environment. Research was conducted by immobilizing strontium waste using Portland pozzolanic cement, white cement and composite Portland cement. Cement, $65 \mathrm{ppm} \mathrm{Sr}\left(\mathrm{NO}_{3}\right)_{2}$, sand and water were mixed and cast. Strontium waste varied in 2 v/o, 4 v/o, 6 v/o and $8 \mathrm{v} / \mathrm{o}$. After 28 days curing, the cement block's compressive strength and leaching rate on saline water were analyzed. Determination of compressive strength was done by using Universal Wood Testing. The density of blocks was measured by picnometer at $25^{\circ} \mathrm{C}$. Compressive strength test for Portland pozzolanic cement at various w/c was conducted to confirm the effect of $\mathrm{w} / \mathrm{c}$ in increasing the strength. For testing strontium leaching rate in water containing $35 \mathrm{ppm} \mathrm{NaCl}$, cement blocks have been immersed in saline water for 21 days. $25 \mathrm{ml}$ samples were taken and analyzed by Atomic Absorption Spectrophotometer. Strontium leaching rate on block containing pH 9 of waste was compared to the previous research data of strontium leaching rate on water to know the effect of saline water. To adjust the $\mathrm{pH}, 1 \mathrm{M}$ $\mathrm{NaOH}$ was added into the waste. Effects of various cement type and filler materials (sand, zeolite and baryte) on Portland pozzolanic cement were also compared. The results show that there were almost no effects of salt on immobilized strontium waste, except in $\mathrm{pH} 9$ waste $\left(0.00224\right.$ over to $0.000199 \mathrm{~g} / \mathrm{cm}^{2} \cdot$ days $)$. Strontium leaching rates on all cemented waste still meet the IAEA's standard, so the safety of cemented strontium waste disposal at saline environment could be ensured.
\end{abstract}

Keywords: Strontium Waste; Immobilization; Cement; Saline Environment

\section{Introduction}

At present, we are facing up to energy problem, especially in the developing countries where many industries are developed. Industries need a stable energy supply that is generated from fossil based power plant up to now and hence, the environmental degradation is becoming the big problem. In the other hand, instability is the main problem of renewable energy. Regarding to these problems, nuclear power plant becomes the only one choice in the frame of sustainable development.

A big problem in the utilization of nuclear power plant is the presence of radioactive waste that has to be stored on an ultimate disposal place for a very long time. To

\footnotetext{
"Corresponding author.
}

finding a proper place for ultimate disposal that meets the standard is not easy, because that place has to have:

- Minimum permeability;

- Maximum flow dispersion;

- Minimum rock gaps;

- Minimum heat interference;

- Maximum ion restraining capacity.

But, the main problem is the social one called NIMBY (not in my back yard) problem. To overcome this problem, there is an idea to store immobilized radioactive waste into the deep sea [1]. The essence of immobilization is waste solidification by mixing waste with a solidifier material in order to protect the environment from radionuclide release. One method of immobilization is cementation. 
Cement used as a solidifier is a hydraulic cement containing $\mathrm{SiO}_{2}, \mathrm{CaO}, \mathrm{Al}_{2} \mathrm{O}_{3}$ and small amounts of $\mathrm{MgO}$, $\mathrm{Fe}_{2} \mathrm{O}_{3}, \mathrm{SO}_{3}$. There are several types of cement, such as Portland cement, composite Portland cement, white cement and pozzolanic cement. Portland cement is the most commonly used cement in many constructions, which does not need special treatment. This type contains $55 \%$ $\mathrm{C}_{3} \mathrm{~S} \quad\left(3 \mathrm{CaO} \cdot \mathrm{SiO}_{2}\right), \quad 19 \% \quad \mathrm{C}_{2} \mathrm{~S} \quad\left(2 \mathrm{CaO} \cdot \mathrm{SiO}_{2}\right), 10 \% \quad \mathrm{C}_{3} \mathrm{~A}$ $\left(3 \mathrm{CaO} \cdot \mathrm{Al}_{2} \mathrm{O}_{3}\right), \quad 7 \% \quad \mathrm{C} 4 \mathrm{AF} \quad\left(4 \mathrm{CaO} \cdot \mathrm{Al}_{2} \mathrm{O}_{3} \cdot \mathrm{Fe}_{2} \mathrm{O}_{3}\right), \quad 2.8 \%$ $\mathrm{MgO}, 2.9 \% \quad \mathrm{SO}_{3}, \quad 1 \%$ ignition loss and $1 \%$ free $\mathrm{CaO} \cdot \mathrm{Ca}(\mathrm{OH})_{2}$ and calcium silicate hydrate $(\mathrm{CSH}$-tobermorite) are produced by the reaction of two calcium silicates compound of cement $\left(\mathrm{C}_{3} \mathrm{~S}\right.$ and $\left.\mathrm{C}_{2} \mathrm{~S}\right)$ with water. Portland cement added with some additives, gypsum for instance, is called composite Portland cement that is used in the UK for immobilized intermediate level waste (ILW) [2]. The heat of hydration in composite Portland cement is lower than Portland cement, and hence it permits using safely for large volume. White cement is formed from $24.2 \% \mathrm{SiO}_{2}, 4.2 \% \mathrm{Al}_{2} \mathrm{O}_{3}, 0.39 \% \mathrm{Fe}_{2} \mathrm{O}_{3}$, $65.8 \% \mathrm{CaO}, 1.1 \% \mathrm{MgO}$ and $0.02 \% \mathrm{Mn}_{2} \mathrm{O}_{3}$. Pozzolanic material is composed of $\mathrm{SiO}_{2}, \mathrm{Al}_{2} \mathrm{O}_{3}, \mathrm{Fe}_{2} \mathrm{O}_{3}, \mathrm{MgO}$ and $\mathrm{SO}_{3}$. To form pozzolanic cement, $15 \%-40 \%$ of pozzolanic materials are added into a Portland cement [3]. Reaction between pozzolanic materials and $\mathrm{Ca}(\mathrm{OH})_{2}$ will reduce porosity.

For storing in deep sea, solidifier material, cement in this case, should be resistance to salt. Sea water contains $3.5 \%$ salt with $\mathrm{NaCl}$ as major compound. Reaction between $\mathrm{NaCl}$ with $\mathrm{Ca}(\mathrm{OH})_{2}$ could disrupt the structure. In addition, in some accident cases, sea water also could flood the radioactive waste temporary storage, for example in Fukushima accident. So, this research's objective is to study the performance of cementation method in immobilizing strontium (a long lived fission product -28 years) waste in saline environment.

\section{Experimental}

For studying the performance of immobilized/cemented strontium waste, two tests were conducted, the compressive strength test and strontium leachate test. The compressive strength test was conducted by immobilizing strontium waste using Portland pozzolanic cement, white cement and composite Portland cement. Cements, 65 ppm $\mathrm{Sr}\left(\mathrm{NO}_{3}\right)_{2}$, and water $(0.3 \mathrm{w} / \mathrm{c})$ were mixed and casted into a cylinder tube having $2.81 \mathrm{~cm}$ of diameter and 5.62 of height. Strontium waste was varied into 2 v/o, 4 v/o, 6 v/o and 8 v/o. After 28 days curing, the compressive strength of cement blocks was analyzed. Determination of compressive strength has been done by using Universal Wood Testing having capacity up to $200 \mathrm{kN}$. The density of blocks was measured by picnometer at $25^{\circ} \mathrm{C}$. The compressive strength test for Portland pozzolanic cement at various w/c $(0.5,0.55,0.6,0.65$ and
0.7) was conducted to confirm the effect of w/c in strength increasing.

For testing the strontium leaching rate on saline water (water contains $35 \mathrm{ppm} \mathrm{NaCl}$ ), cement blocks were immersed on saline water for 21 days. $25 \mathrm{ml}$ samples were taken in the $2^{\text {nd }}, 4^{\text {th }}, 6^{\text {th }}, 9^{\text {th }}, 12^{\text {th }}, 15^{\text {th }}, 18^{\text {th }}, 21^{\text {st }}$ days and analyzed by Atomic Absorption Spectrophotometer. The strontium leaching rate on block containing $\mathrm{pH} 9$ of waste was compared to the data of strontium leaching rate on water by Nunung Prabaningrum et al. (1999) [4] to know the effect of saline water. To adjust the $\mathrm{pH}, 1 \mathrm{M}$ $\mathrm{NaOH}$ was added into the waste. The effects of various cement type and filler materials (sand, zeolite and baryte) on Portland pozzolanic cement were also compared.

\section{Results and Discussion}

\subsection{The Compressive Strength Test}

According to the IAEA Technical Report Series No.222, the concrete resulted from the cementation process is required to meet the quality criteria [5]:

- Density: $1.70-2.50 \mathrm{~g} / \mathrm{cm}^{3}$;

- Compressive strength: $20-50 \mathrm{~N} / \mathrm{mm}^{2}$;

- Compressive strength after waste loading: $2.5 \mathrm{~N} / \mathrm{mm}^{2}$;

- Leaching rate $(\mathrm{Rn}): 1.70 \times 10^{-1}-2.50 \times 10^{-4} \mathrm{~g} /$ $\mathrm{cm}^{2} \cdot$ days;

- Dose rate in contact surface: $2 \mathrm{mSv} / \mathrm{hr}$;

- Dose rate at 1 meter from contact surface: $<0.10$ $\mathrm{mSv} / \mathrm{hr}$;

- Dose rate outside of interim storage: $0.005 \mathrm{mSv} / \mathrm{hr}$.

The Russian Federation standard requires higher compressive strength than IAEA standard $\left(5 \mathrm{~N} / \mathrm{mm}^{2}\right)$ [2].

The compressive strength test result for various cement type at various waste loading showed that almost of all cement types have a compressive strength over the IAEA standard $\left(2.5 \mathrm{~N} / \mathrm{mm}^{2}\right)$ as shown in Figure 1, moreover the Russian Federation one. The $\mathrm{C}_{3} \mathrm{~S}$ amount in composite Portland cement is higher than in white cement (52 w/o:48.5 w/o), as consequently composite Portland cement has higher compressive strength as shown in Table 1. Composite Portland cement also has lower heat of hydration, and hence it results in denser cement block.

Portland pozzolanic cement has lowest strength due to its lowest density as shown in Table 1. Table 2 shows that Portland pozzolanic cement has lowest $\mathrm{C}_{3} \mathrm{~S}$ that play a role in cement hardening at early stage. Cement with high $\mathrm{C}_{2} \mathrm{~S}$ hydrates much more slowly leading to a denser ultimate structure [2], therefore to get a good strength, Portland pozzolanic cement needs much more curing time. According to Susetyo et al. (2013), the compressive strength of Portland pozzolanic cement is affected by w/c [3]. The workability of cement on $0.3 \mathrm{w} / \mathrm{c}$ was very low that resulted in presence of macro porosity. Greater strength was obtained in higher w/c as shown in Figure 2. 


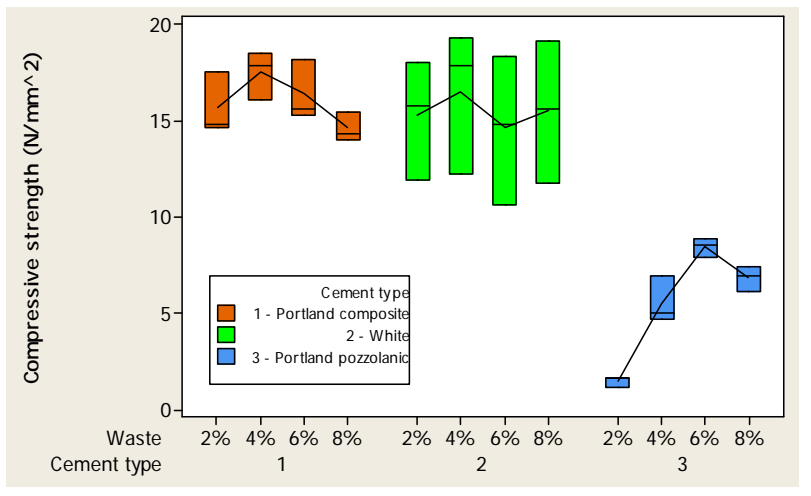

Figure 1. Boxplot of compressive strength of all cement types.

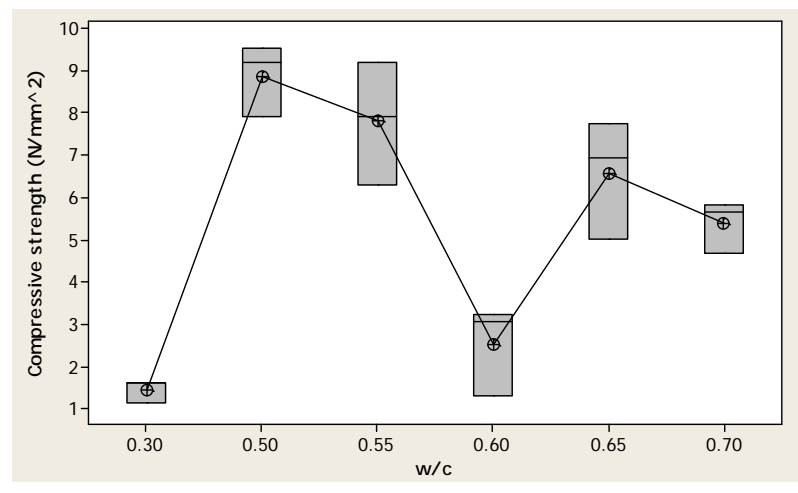

Figure 2. Boxplot of compressive strength of Portland pozzolanic cement at various w/c.

Table 1. Density of each cement type at $25^{\circ} \mathrm{C}$ checked by picnometer.

\begin{tabular}{cc}
\hline Cement type & Density $(\mathrm{g} / \mathrm{ml})$ \\
\hline White cement & 2.4563 \\
Portland composite cement & 2.631 \\
Portland pozzolanic cement & 1.66 \\
\hline
\end{tabular}

Table 2. Compounds composition on each cement.

\begin{tabular}{cccc}
\hline Compound & $\begin{array}{c}\text { Portland } \\
\text { composite }\end{array}$ & White & $\begin{array}{c}\text { Portland } \\
\text { pozzolanic }\end{array}$ \\
\hline $\mathrm{C}_{3} \mathrm{~S}\left(3 \mathrm{CaO} \cdot \mathrm{SiO}_{2}\right)$ & $52 \%$ & $48.5 \%$ & $14.55 \%$ \\
$\mathrm{C}_{2} \mathrm{~S}\left(2 \mathrm{CaO} \cdot \mathrm{SiO}_{2}\right)$ & $12 \%$ & $30.5 \%$ & $62.05 \%$ \\
$\mathrm{C}_{3} \mathrm{~A}\left(3 \mathrm{CaO} \cdot \mathrm{Al}_{2} \mathrm{O}_{3}\right)$ & $8 \%$ & $13.4 \%$ & $13.11 \%$ \\
$\mathrm{C}_{4} \mathrm{AF}\left(4 \mathrm{CaO} \cdot \mathrm{Al}_{2} \mathrm{O}_{3} \cdot \mathrm{Fe}_{2} \mathrm{O}_{3}\right)$ & $9 \%$ & $0.8 \%$ & $10.32 \%$ \\
$\mathrm{Mn}_{2} \mathrm{O}_{3}$ & & $0.02 \%$ & \\
\hline
\end{tabular}

According to MacLaren, D.C., dan White, M.A. (2003), the increasing of $\mathrm{w} / \mathrm{c}$ results in larger pores that is able to lead to the acceleration of drying process. The content of free water in large pores will evaporate quickly that can lead to generate micro cracking [6]. Therefore, it is rea- sonable that there is a decreasing of compressive strength over $0.5 \mathrm{w} / \mathrm{c}$. The ANOVA analysis shown in Table 3 below also confirm the argument that shows the P-values of w/c is lower than the $i$-value $(0.05)$. It means that the variations of variable result in the difference responses.

\subsection{The Strontium Leaching Rate Test on Saline Water}

On saline water $\mathrm{Ca}(\mathrm{OH})_{2}$ on cement will react following reaction: 1) that destructs cement blocks following reaction; 2) and hence, strontium will be easier to diffuse into the water:

$$
\begin{aligned}
\mathrm{Ca}(\mathrm{OH})_{2}+2 \mathrm{NaCl} & \rightarrow 2 \mathrm{Na}(\mathrm{OH})+\mathrm{CaCl}_{2} \\
\mathrm{CaCl}_{2}+\mathrm{C}_{3} \mathrm{~A}_{\text {aq }} & \rightarrow \mathrm{C}_{3} \mathrm{~A} \cdot \mathrm{CaCl}_{2 \mathrm{aq}}
\end{aligned}
$$

These reactions result in increasing of strontium leaching rate with $\mathrm{pH} 9$ of waste on saline water compared to leaching rate in water ( 0.00224 over to 0.000199 $\mathrm{g} / \mathrm{cm}^{2} \cdot$ days). However, it still meets IAEA's standard $\left(10^{-2} \mathrm{~g} / \mathrm{cm}^{2} \cdot\right.$ days $)$.

But, when the Nunung's data compared to the other blocks loading pH 6 of waste, it could be conclude that there are no effect of saline water on strontium leaching rate $\left(0.0000049-0.0000068 \mathrm{~g} / \mathrm{cm}^{2} \cdot\right.$ days $)$. The $\mathrm{pH}$ adjustment in this study was done by adding $\mathrm{NaOH}$ on the waste. $\mathrm{NaOH}$ will react with $\mathrm{CaO}$ on cement to form $\mathrm{Ca}(\mathrm{OH})_{2}$. The excessive $\mathrm{Ca}(\mathrm{OH})_{2}$ will obstructed the setting process of cement.

The mentioned above reactions could be avoided when there is no cracking or hole in surface, and hence $\mathrm{NaCl}$ could not penetrate into the gaps between pores of block. The presence of cracking or pore will reduce cement block density and as consequently increase leaching rate. Figure 3(a) shows that there is an impact of density on strontium leaching rate. A similar result was also obtained when we varied the filler (Figure 3(b)).

Figure 3(b) shows that the $2^{\text {nd }}$ days strontium leaching rate in zeolite filled block is the highest one. Zeolite could be used as adsorber and ion exchanger, so it should adsorb strontium well. But, on saline water, $\mathrm{Na}^{+}$ion is easier to exchange $\mathrm{Sr}^{2+}$ and then exchanged $\mathrm{Sr}$ on block surface is diffused back into the water. Sand also could be used as adsorber and experiences a similar reaction

Table 3. Result of one-way ANOVA on compressive strength of Portland pozzolanic cement at various w/c.

\begin{tabular}{cccccc}
\hline Source & DF & SS & MS & F & P \\
\hline w/c & 5 & 128.85 & 25.77 & 24.04 & 0.000 \\
Error & 12 & 12.86 & 1.07 & & \\
Total & 17 & 141.71 & & &
\end{tabular}

$\mathrm{S}=1.035, \mathrm{R}-\mathrm{Sq}=90.92 \%, \mathrm{R}-\mathrm{Sq}(\operatorname{adj})=87.14 \%$. 


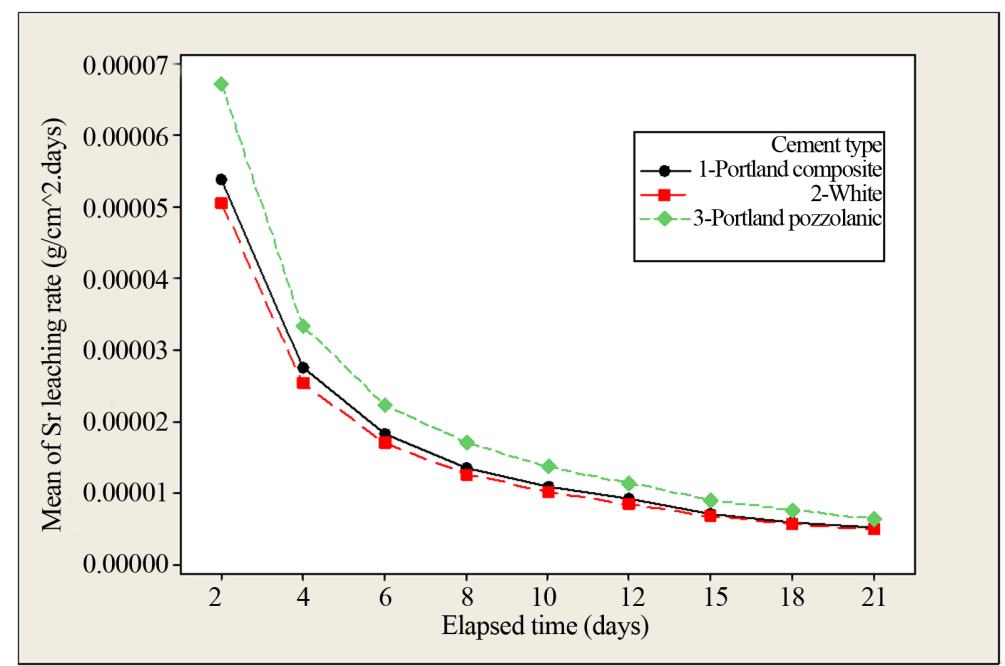

(a)

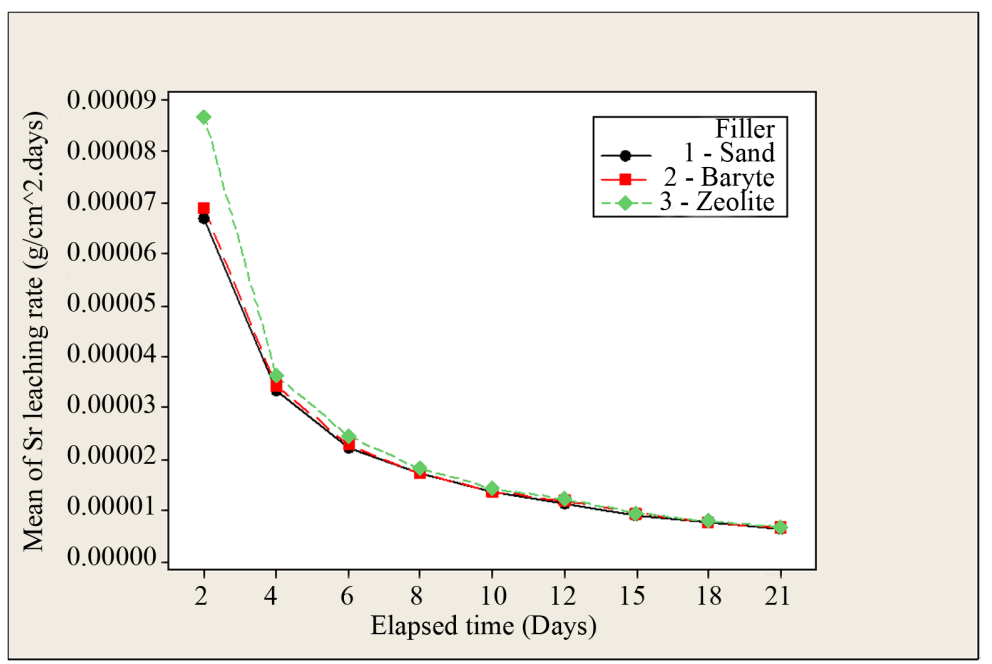

(b)

Figure 3. Sr leaching rate (a-upper) in various cement and (b-below) in various filler.

with zeolite. But, it is believed that the smaller grain size of zeolite ( \pm 40 mesh to \pm 20 mesh of sand) causes the phenomena. A smaller grain size will expand the contact surface and increase adsorb capacity, but in the other hand, exchangable $\mathrm{Sr}^{2+}$ is also much greater than in sand one. Baryte rock has no adsorb capacity, but the addition of baryte could increase the density of block $\left(2.07 \mathrm{~g} / \mathrm{cm}^{3}\right.$ to $1.66-1.69 \mathrm{~g} / \mathrm{cm}^{3}$ of sand and zeolite) and block the intrusion of $\mathrm{NaCl}$.

\section{CONCLUSION}

The results show that there were almost no effects of saline water on immobilized strontium waste, except in $\mathrm{pH} 9$ of waste $\left(0.00224\right.$ over to $0.000199 \mathrm{~g} / \mathrm{cm}^{2}$.days $)$. The strontium leaching rates on all immobilized waste still meet the IAEA's standard $\left(10^{-2} \mathrm{~g} / \mathrm{cm}^{2} \cdot\right.$ days $)$, and hence the safety of immobilized strontium waste disposal at saline environment could be ensured.

\section{Acknowledgements}

The authors gratefully acknowledge the support of the Department of Engineering Physics, Universitas Gadjah Mada.

\section{REFERENCES}

[1] Y. S. Tang and J. H. Saling, "Radioactive Waste Management," Hemisphere Publishing Corporation, New York, 1990.

[2] M. I. Ojovan and W. E. Lee, "An Introduction to Nuclear Waste Immobilisation,” Elsevier Inc., Oxford, 2005.

[3] S. H. Putero, W. Rosita, et al., "The Performance of Various Pozzolanic Materials in Improving Quality of Strontium Liquid Waste Cementation," Procedia Environmental Science, Vol. 17, 2013, pp. 703-710. 
[4] A. A. Prabaningrum and W. A. W. Supardi, "The Effect of Ca-Bentonite Additive on the Cementation of Radioactive Concentrate Waste Containing Sodium Nitrate," Proceedings of the 2nd Biannual International Workshop on High Level Radioactive Waste Management, Yogyakarta, 10-12 August 1999, pp. 81-90.

[5] H. Poernomo and R. dan Supardi, "Pengaruh Natrium Silikat Terhadap Sementasi Limbah Uranium yang Mengandung Ammonium Flourida," Prosiding Pertemuan dan Presentasi Ilmiah Penelitian Dasar Ilmu Pengetahuan dan Teknologi Nuklir, Yogyakarta, 25-27 April 1995, pp. 340-345.

[6] D. C. MacLaren and M. A. dan White, "Cement: Its Chemistry and Properties," Journal of Chemical Education, Vol. 80, No. 6, 2003, pp. 623-635.

http://dx.doi.org/10.1021/ed080p623 